УДК: 339.138:004.738.5

JEL: F1, F14

Шаповал Богдан Сергійович

аспірант, Громадська Спілка «Ю-Фуд»,

Умань, Україна

ORCID ID: 0000-0001-9242-0552

e-mail:kardvalr@gmail.com

\title{
КОМУНІКАЦІЇ ПРИ ЕКСПОРТІ ХАРЧОВИХ ПРОДУКТІВ У В2В ТА В2С СЕКТОРАХ ПРОДОВОЛЬЧОГО РИНКУ
}

Анотація. Метою дослідження є ознайомлення з чинниками що сприяють експорту продукції 3 країни, процесами підготовки виробників харчової продукції до експорту та продажами в секторах В2В та В2C, різницею між ними та необхідними маркетинговими заходим для різних секторів. В процесі аналізу було виявлено товарні позиції харчових продуктів що найбільше експортувались в 2019 році. Дослідження було проведене за методикою збору наукової інформації про маркетингові комунікації в В2В та В2С секторах, їх порівняння та аналізу. В процесі дослідження було досліджено мотиви виробників харчових продуктів що спонукають їх до експорту, необхідні для експорту кроки та процедури, різні типи співпраці з іноземними та внутрішніми покупця та різницю між ними. А також різницю між співпрацею $з$ покупцями з сектору Бізнес до Бізнесу та Бізнес до Споживача. Означено необхідність постійної комунікації з обома секторами та доцільність використання інтернет ресурсів для забезпечення якісної комунікації. Досліджено різницю в маркетингових комунікаціях в вищезгаданих секторах, та особливості вибору кожного з потенційних клієнтів. В статті також описано розбіжності у роботі та маркетингових комунікаціях в секторах Бізнес до Бізнесу та Бізнес до Споживача. Надані у статті рекомендації сприяють ознайомленню виробників харчових продуктів з процедурою експорту харчових продуктів, необхідною підготовкою підприємств до експорту та взаємодії з різними типами клієнтів. Стаття також включає в себе ключові чинники що спонукають представників обох секторів до покупки та потенційні ризики у роботі 3 ними для виробників харчових продуктів. Надано рекомендації для виробників харчових продуктів 3 документації та сертифікації продукції та підприємства необхідних для початку експорту та пошуку потенційних клієнтів в іншій країні.

Ключові слова: експорт харчових продуктів; вибір експортного ринку; маркетингові комунікації; бізнес до бізнесу; бізнес до споживача; підготовка підприємства до експорту.

\section{DOI: http://doi.org/10.32750/2020-0213}

\section{ВСТУП}

Частою проблемою країн що розвиваються є питання надлишку виробництва, не зважаючи на те, що економіка в них є менш продуктивною ніж у промислових країн. Для вирішення проблем надлишку виробництва виробники шукають ринки збуту в інших країнах. Для прикладу Кот-д’Івуар виробляе надлишкову кількість какао, а Латинська Америка має надлишок виробництва кави, обидві країни мають не достатню кількість населення в порівнянні з виробництвом згаданих продуктів, і експортують продукцію до країн де цей продукт не виробляється. Експорт продукції та товарів допомагає країнам розвивати власну економіку, та дає можливість імпортувати іноземну продукцію, що не виробляється країною.

Постановка проблеми. Важливою частиною підготовки підприємства до експорту продукції за кордон є дослідження ринку та підготовка до виходу на нього. Цей етап включає в себе отримання всіх необхідних для експорту сертифікатів та дозволів, та створення маркетингової та експортної стратегій. Для ефективної маркетингової та експортної стратегії важливо визначитись з сектором роботи на новому ринку.

Аналіз останніх досліджень та публікацій. Вагомий внесок в дослідження маркетингових комунікації, підготовки до експорту продукції, типів споживачів та 
різниці у співпраці з ними внесли такі вчені як Духницький Б., [1], Наварро А., Рондан Ф. Дж., Ацедо Ф.Дж., [3], Повольна Л., [4], Макдональд М., [5], Реклайтіс К. Пілеліне Л. [7], Зіммерманн А. [6], Маліновська М. [8], Камільєрі М. [9], Дуралія О. [10], Кітчен П. [11], Кумар В. [12], Оуен Р. Хамфрі П. [13], Саха С. Хоссейн М. Іслам А. Родела Р. [14], Рехман У. Ібрагім М. [15], Бітс М. Гандлі А. [16], Тодорова Г. [17], Кі Ч. Чаплевський А. [18], Кім К. Кумар В. [19],. Але з розвитком країн розвиваються і ринки, тому кількість необхідної для експорту інформації все зростає. Для успішного експорту необхідно знати свого клієнта та передбачувати його кроки.

Мета статті. Дослідити спільні риси та відмінності у комунікаціях в секторах Бізнес до Бізнесу та Бізнес до Споживача. Надати рекомендації з підготовки підприємств харчової промисловості до експорту продукції.

\section{РЕЗУЛЬТАТИ ДОСЛІДЖЕННЯ}

Вітчизняний ринок агропродовольчої продукції зазнав багатьох структурних змін за період незалежності, включаючи відхід від планово-командної системи господарювання, проведення аграрної реформи на селі та функціонування в умовах вимушеної переорієнтації виробничоекспортної діяльності. Однак він все одно залишається чи не найбільш важливою ланкою економіки України, самостійно формуючи iï продовольче забезпечення та створюючи імідж провідного гравця на світовому ринку сільськогосподарської продукції [1, с. 4].

Експорт продукції з України

\begin{tabular}{|l|c|}
\hline \multicolumn{1}{|c|}{ Назва товарів } & $\begin{array}{c}\text { Обсяг експорту (тис. } \\
\text { доларів США) }\end{array}$ \\
\hline Бакалійна група & 9633332 \\
\hline Жири та олії тваринного або рослинного походження & 4732236 \\
\hline Насіння і плоди олійних рослин & 2563243 \\
\hline М'ясо та їстівні субпродукти & 711894 \\
\hline Молоко та молочні продукти; яйця птиці & 453876 \\
\hline Їстівні плоди та горіхи & 260108 \\
\hline Цукор і кондитерські вироби з цукру & 254390 \\
\hline Алкогольні і безалкогольні напої та оцет & 210821 \\
\hline
\end{tabular}

Експортну готовність компанії можна продемонструвати різними способами, але ніщо не відображає зобов'язання фірми щодо експорту більше, ніж іiі бажання адаптуватися до задоволення потреб, та очікувань іноземних споживачів, що означатиме адаптацію тих елементів маркетингової програми, які потребують модифікації [3, с. 254].

В першу чергу перед пошуком імпортерів 3 інших країн, необхідно оцінити готовність компанії та продукції до експорту. Для визначення найсприятливішого ринку для експорту варто проаналізувати імпортні категорії світу. В першу чергу виділити країни що найбільше імпортують аналогічний продукт, дослідити культуру, умови співпраці, необхідні документи та сертифікати, та традиції споживання обраної продукції в країні.

Також, перед плануванням експорту, компанії необхідно розпланувати експортну стратегію, провести дослідження потенційного експортного ринку, враховуючи всі позитивні та негативні чинники що можуть мати вплив на ринок та споживачів. Необхідно дослідити ринкові маршрути, методи експорту та головних гравців на ринку. Після ознайомлення з умовами продажу, оптовою та роздрібною вартістю на продукцію 
та способами проведення платежів між країнами варто ознайомитись і з умовами страхування вантажу та платежів.

Орієнтована на експорт продукція повинна відповідати не тільки міжнародним стандартам, а й вимогам країни імпортера. Через різницю в культурі між країнами, продукт може потребувати адаптації та модифікацій, це може стосуватись упаковки, маркування, або навіть складу продукції. Для експорту продукції, компанія має мати достатньо великі виробничі потужності, операційний досвід, або спеціалістів 3 необхідним досвідом. Після детального аналізу компанії та цільового ринку, необхідно сформувати план з підготовки компанії до експорту.

Перед пошуком імпортера в обраній країні, необхідно визначити готовність продукту компанії до продажу в країні. Представники малого та середнього бізнесу зазвичай не мають достатніх для повноцінного маркетингового дослідження ресурсів на відміну від великого бізнесу що володіє відомими торгівельними марками.

Перше, що має зробити компанія перед початком експорту, це відповісти на питання хто буде їх покупцем, чи буде це кінцевий споживач, чи інший бізнес. Бізнес до Бізнесу зазвичай означає продаж своєї продукції тільки іншим підприємствам, це можуть бути оптові покупці, але не кінцеві споживачі. Бізнес до споживача в свою чергу означає продаж продукцію напряму кінцевому споживачу.

Ринок роботи в форматі бізнес до споживача зазвичай є регіонально обмеженим, може також бути обмеженим кількістю людей в країні чи регіоні.

Також, компаніям необхідно визначитись 3 формою роботи з іноземним ринком: Business to Business чи Business to Customer. Перший варіант можливої співпраці більше підходить для малого та середнього бізнесу, через меншу потребу в інвестиціях з боку компанії експортера. Другий варіант є більш доступним для представників великого бізнесу, так як може потребувати інвестицій в адаптацію продукту, його дистрибуцію в іншій країні та маркетингові заходи зорієнтовані на просування торгівельної марки на іноземному ринку.

Кожна 3 категорій має свої переваги та недоліки. Бізнес до Бізнесу дозволяє експортерам продавати продукцію великими об'ємами, та прослідковувати товарні партії, до того ж така форма співпраці $є$ найбільш зручною для промислового використання. Бізнес для споживача в свою чергу, дає виробнику можливість розподілення продукції на мінімальні тари для різних цільових груп, що можуть вміщувати в себе різні товарні позиції.

В формі роботи Бізнес до Бізнесу, співпраця довгий час базувалась на особистому контакті з партнерами. Але $з$ розвитком інтернет технологій комунікація все частіше переходить в режим онлайн, за прогнозами ця тенденція зберігатиметься і надалі. В сучасному світі закупівельними у секторі Бізнес до Бізнесу часто вимагаюсь до себе особистої уваги та особливого підходу. Для започаткування успішних та довготривалих торгівельних стосунків, важливо час від часу відвідувати країну експорту та продовольчі виставки проведені в ній для особистих зустрічей з колишніми, теперішніми та потенційними замовниками.

Варто розуміти, що вже існуючі клієнти є набагато важливішими для компанії ніж нові та потенційні покупці. Часто, компанії втрачають клієнтів, через недостатнє розуміння своїх споживачів, з цієї ж причини потенційні покупці так і не переходять в фактичних. Споживачі можуть не правильно зрозуміти запропоновану їм вартість, через неякісно виконане позиціонування продукту. Для повного розуміння клієнта необхідна постійна співпраця з відділами маркетингу та збуту. До того ж, надзвичайно корисно спілкуватись з своїми споживачами та питати їх, що переконало їх зробити покупку. 
Покупці В2В орієнтовані на збір інформації для зменшення ризиків за допомогою коментарів та думок інших - вони шукають відповідну інформацію. Використання правильної інформації та популярність вмісту стали конкурентною перевагою фірми на ринку. Тому маркетологи намагаються впровадити стратегії, які заохочуватимуть взаємодію клієнтів з метою впливу на продажі, генерувати потенційних клієнтів, будувати відносини, підвищувати впізнаваність бренду та лояльність або пришвидшити рішення про покупку. У контексті соціальних мереж популярність контенту впливає на продажі, бренд, ефективність бренду, лояльність та рентабельність інвестицій у соціальних мережах [4, с. 3].

Якщо поняття «маркетинг» означає всі ті заходи, пов'язані зі створенням i задоволенням попиту та пов'язаними з ними розвідками, тоді очевидно, що більшість елементарних маркетингових заходів відбувається під час процесу надання технічної послуги або під час неформальних контактів із клієнтами. Таким чином, у таких ситуаціях термін „маркетинг” відображає цю подвійність і виступає як термін як маркетингу, так і надання технічних послуг [5, с. 750].

У секторі В2В компанії зосереджуються на логіці товару та його особливостях. Клієнти також досліджують конкурентів та альтернативні рішення; тому консультативний підхід повинен переважати у маркетинговому спілкуванні В2В проти агресивного підходу до укладення угод. У той же час маркетингова комунікація В2С спрямована на кінцевого споживача, вибір якого часто нераціональний; а продавець захоче зосередитись на перевагах товару або послуги [6, с. 5]. Кампанія маркетингових комунікацій В2С в більшості випадків базуватиметься на негайному приверненні уваги клієнта.

Рішення споживачів будуть більш емоційними: вони не будуть надавати стільки часу аналізу інших альтернатив чи конкурентів; проте іноді їх також можуть цікавити особливості та переваги продуктів чи послуг. Однак наголос на емоціях часто придушує належне націлювання, що призводить до руйнівних та нерелевантних для споживачів повідомлень, які часто розуміють як шум навколишнього середовища [7, с. 78].

Сучасні інструменти відстеження та маркетингові технології виявили одне: набивання якомога більшої кількості потенційних клієнтів у воронку продажів і сподівання на найкраще вже не є життєздатним підходом до ведення бізнесу. На щастя, автоматизація маркетингу використовує змішану модель оцінювання, щоб запропонувати елегантне рішення для вирішення кваліфікаційних завдань.

Через мультисенсорний характер продажів В2В маркетологи не повинні панікувати, якщо не зможуть зібрати всю необхідну інформацію про потенційних клієнтів під час першої взаємодії [8, с. 133]. Кожна точка дотику надає можливість зібрати більше даних та створити профіль потенційного клієнта 3 часом. За наявності інструменту автоматизації маркетингу, стає можливим використовувати прогресивне профілювання, щоб динамічно представляти користувачам нові запитання кожного разу, коли вони отримують доступ до форми (приховуючи поля, які вони вже заповнили) [9, c. 96].

Це зменшує навантаження на потенційних клієнтів, одночасно дозволяючи збирати цінну інформацію, необхідну командам маркетингу та продажів для просування вперед. Будуючи маркетингову стратегію до роботи у форму Бізнес до Бізнесу, необхідно мати ефективне виробництво, кваліфікувати постійних клієнтів та не втрачати з ними зв'язок, регулярно оновлювати свої контактні бази даних та постійно оновлювати методи спілкування [10, с. 98].

Загальний ринок сектору Бізнес до Бізнесу, включає в себе всі установи, що можуть купувати велику кількість продукції, крім підприємств оптової торгівлі ще й лікарні, 
благодійні організації, і всі рівні управління. Це $є$ особливо актуальним в умовах де квазідержавні операції можуть бути найбільшими замовленнями в країні [11, с. 397]. Великі держані та приватні установи часто купують продукцію аби збільшити свій прибуток від іiі продажу. Інституційні покупці мають ті ж проблеми, але вони більше зосереджені на забезпечення достатнього наявності достатнього надлишку.

Наразі, існує лише два основні способи збільшення прибутку від продажу продукції: збільшення продажів та зменшення витрат. Ці цілі можуть бути досягнуті за рахунок підвищення ефективності відділу збуту або придбання продуктів за дешевшими цінами [12, с. 449]. Найефективніші маркетингові програми орієнтуються на бізнеспокупців та базуються на одному з трьох: збільшенні продажів, зменшенні витрат та дотриманні урядових норм та уникненні негативної слави.

Продажі у секторі Бізнес до Бізнесу значно різняться від продажів у секторі Бізнесу до Споживача. В першу чергу різняться розміри потенційних ринків [13, с. 5]. Працюючи в В2С секторі виробники мають можливість розповсюджувати продукцію, та шукати партнерів на більшому ринку ніж виробники що працюють у В2В секторі, тому що потенційними покупцями у першому випадку $\epsilon$ все населення країни, а в іншому тільки компанії з специфічною діяльністю.

Від сектора до сектора різниться також і рівень продажів, у випадку роботи 3 іншими підприємствами він є значно більшим. Також, при здійсненні замовлення споживач робить вибір самостійно, в той час коли В2В клієнт повинен обговорити вибір продукції 3 керівництвом або комітетами. В той же час, в роботі 3 кінцевими споживачами напряму значно менші ризики ніж у роботі з дистриб'юторами чи агентами [14, c. 197].

Вибір сектору впливає також і на процес покупки, у випадку роботи 3 іншим бізнесом процес формулювання та узгодження замовлення може зайняти до одного року. Багато часу може зайняти і отримання платежу за продукцію, в той час коли платіж від кінцевого споживача можна отримати миттєво у формі готівки або сплати карткою, в роботі з дистриб'ютором може бути необхідна відстрочка. Транзакції між кордонами можуть також мати додаткові затримки або комісії від різних банків [15, с. 4].

Споживачі часто роблять покупки під впливом емоцій, коли вибір В2В клієнта буде заснованим на раціональному рішенні та обговоренні з колегами чи керівництвом $[16$, с. 3]. В роботі 3 обома секторами доцільним для просування продукції $\epsilon$ використання інтернет ресурсів та соціальних мереж.

У випадку В2С маркетингу основною ціллю компанії є продаж, а точніше вибір покупця витратити власні кошти на запропонований товар. Але вчені також підкреслюють що у співпраці 3 потенційними та існуючими покупцями варто створювати постійну та надійну комунікацію, аби збільшити цінність торгівельної марки. Для досягнення різних цілей зорієнтованих для підвищення впізнаваності бренду серед споживачів варто використовувати різні інструменти, i за їх допомогою інформувати людей про особливості та переваги пропозицій компанії [17, с. 370].

Зі сторони маркетолога здається ніби робота в секторах В2В та В2С значно різниться та за основу має припущення складності, ціноутворення, просування та прийняття рішень, але є в цих секторах і багато спільного. Найвагомішим спільним фактором $\epsilon$ зорієнтованість на споживача. Ціллю маркетингових комунікацій $\epsilon$ якнайбільше охоплення цільової аудиторії чітким та влучним повідомленням [18, с. 330].

Маркетингові повідомлення можуть також різнитись в залежності від місця їх розміщення. Повідомлення для сектору В2С в більшості вимагає від споживача нагальних дій: скористатись знижкою, ввести промо код, зареєструватися за посиланням або навіть придбати продукцію одразу зі знижкою. Повідомлення у секторі 
B2В є більш інформативними, їх завданням є зацікавлення покупця цікавою та новою інформацією та створення у нього бажання дізнатись про продукт чи пропозицію більше [19, с. 54].

Таблиия 2

Підтримка продажів

\begin{tabular}{|l|l|}
\hline \multicolumn{1}{|c|}{ Бізнес до Бізнесу } & \multicolumn{1}{c|}{ Бізнес до споживача } \\
\hline Співпраця з постійними клієнтами & Введення нових товарних позицій \\
\hline Лояльність до клієнтів & Моніторинг споживчих вподобань \\
\hline Готовність до можливих адаптацій & Дослідження цільових груп \\
\hline Відстрочка платежів при перших замовленнях & Агресивний маркетинг \\
\hline
\end{tabular}

Для компаній що не бажають розмежовуватись у просуванні продукції на різні сектори є також варіант змішаних маркетингових комунікацій. Змішані маркетингові комунікації включатимуть в себе рекламу в медійному просторі та інтернет ресурсах, особисті продажи та стимулювання процесу збуту продукції, зв'язки з громадськістю, цифровий та прямий маркетинг. Витрати на всі перелічені форми маркетингових комунікацій також різняться.

Виробники харчових продуктів з середнього або великого бізнесу мають більше можливостей для просування своєї продукції різними каналами. Бренди харчових продуктів можна просувати через електронні засоби масової інформації, а саме телебачення або радіо, через друковані засоби масової інформації, а саме газети та журнали, та через електроповідомлення або телемаркетинг. В секторі В2С можна зменшити витрати на маркетингові комунікації приділяючи більше уваги якісному контенту.

\section{ВИСНОВКИ ТА ПЕРСПЕКТИВИ ПОДАЛЬШИХ ДОСЛІДЖЕНЬ}

В результаті проведеного дослідження було виявлено головні відмінності та спільні особливості маркетингових комунікацій в секторах В2В та В2С. Використання інтернет ресурсів для просування продукції та комунікацій з потенційними клієнтами показало свою результативність в обох секторах. Однак обов'язковою вона є тільки для сектору $\mathrm{B} 2 \mathrm{C}$.

Значна різниця $є$ у розподілі бюджету для маркетингових комунікацій, виробники що більше працюють 3 сектором В2В мають більше бюджетних коштів для маркетингових комунікацій, але не виявляють достатньої готовності до витрат коштів саме на маркетинг. Недовіра є зрозумілою враховуючи те, що в секторі В2В більше ваги має особисте спілкування.

\section{СПИСОК ВИКОРИСТАНИХ ДЖЕРЕЛ}

1. Духницький Б. В. Потенціал розвитку агропродовольчого ринку України. Економіка АПК. 2019. № 11. C. $27-34$.

2. Trade map, URL: https://www.trademap.org/Index.aspx

3. Navarro, A., Rondán, F. J., \& Acedo, F. J. The importance of an export-oriented culture for export performance. European Journal of International Management. 2013.7 (3). C. 254

4. Povolná, L. Marketing Communications on B2B Markets. Conference Proceedings of 13th Annual International Bata Conference for Ph.D. Students and Young Researchers, Tomas Bata University in Zlín, Czech Republic. 2017.

5. McDonald, M., Marketing in B2B organisations: as it is; as it should be - a commentary for change. Journal of Business \& Industrial Marketing. 2016 Vol. 31 No. 8, pp. 961-970. 2013.

6. Alan Zimmerman and Jim Blythe, Business to Business Marketing Management. A Global Perspective.,

7. Réklaitis Kestutis, and Lina Pileliené. Principle Differences between B2B and B2C Marketing Communication Processes. Management of Organizations: Systematic Research 2019. 81: 73-86. 
8. Malinowska, M. Marketing Communications' Effectiveness in Poland - Lessons from the Business in Information Society // The Central European Journal of Social Sciences and Humanities. 2013 Vol. 150, pp. 133143

9. Camilleri, M. A. Integrated Marketing Communications / In Travel Marketing, Tourism Economics and the Airline Product. - Cham, Switzerland: Springer Nature, 2018 pp. 85-103

10. Duralia, O. Integrated Marketing Communication and its Impact on Consumer Behavior Studies in Business and Economics. 2018 Vol. 13, Issue 2, pp. 92-102. doi:10.2478/sbe-2018-0022.

11. Kitchen, P. J. Integrated Marketing Communications. Evolution, Current Status, Future Developments. European Journal of Marketing. 2017 Vol. 51, Issue 3, pp. 394-405. doi:10.1108/EJM-06-2016-0362.

12. Kumar, V., Raheja, G. Business to Business (B2B) and Business to Consumer (B2C) Management. International Journal of Computers \& Technology. 2012 Vol. 3, No. 3, pp. 447-451.

13. Owen, R., Humphrey, P. The Structure of Online Marketing Communication Channels. Journal of Management and Marketing Research. 2010 Vol. 2, pp. 1-10.

14. Saha, S. K., Hossain, M. Sh., Islam, A., Rodela, R. S. A Comparative Study on B2B Vs. B2C Based on Asia Pacific Region. International Journal of Scientific \& Technology Research. 2014 Vol. 3, Issue 9, pp. 294298

15. Rehman, U. Sh., Ibrahim, M. S. Integrated Marketing Communication and Promotion. Journal of Arts, Science \& Commerce. 2011 Vol. 2, Issue 4, pp. 1-5

1. Murton Beets, L., Handley, A. B2C Content Marketing. 2019. Internet access: <https://contentmarketinginstitute.com/wp-content/uploads/2018/12/2019_B2C_Research-FINALPDF12_10_18.pdf>, [accessed July 13, 2019].

16. Todorova, G. Marketing Communication Mix. Trakia Journal of Sciences. 2015 Vol. 13, Suppl. 1, pp. 368-374. doi:10.15547/tjs.2015.s.01.063.

17. Key, Th. M., Czaplewski, A. J. Upstream Social Marketing Strategy: An Integrated Marketing Communications Approach. Business Horizons. 2017 Vol. 60, Issue 3, pp. 325-333. doi:10.1016/j.bushor.2017.01.006

18. Kim, K. H., Kumar, V. The Relative Influence of Economic and Relational Direct Marketing Communications on Buying Behavior in Business-to-Business Markets. Journal of Marketing Research. 2018 Vol. 55, No. 1, pp. 48-68. doi:10.1509/jmr.16.0283. 


\section{Шаповал Богдан Сергеевич}

аспирант, Общественная Организация «Ю-Фуд»,

Умань, Украина

ORCID ID: 0000-0001-9242-0552

e-mail: kardvalr@gmail.com

\section{КОММУНИКАЦИИ ПРИ ЭКСПОРТЕ ПИЩЕВЫХ ПРОДУКТОВ В В2В И В2С СЕКТОРАХ ПРОДОВОЛЬСТВЕННОГО РЫНКА}

Аннотация. Целью исследования является ознакомление с факторами способствующими экспорту продукции из страны, процессами подготовки производителей пищевой продукции к экспорту и продажами в секторах В2В и В2С, разницей между ними и необходимыми маркетинговыми мероприятиями для различных секторов. В процессе анализа было выявлено товарные позиции пищевых продуктов которые больше всего экспортировались в 2019 году. Исследование было проведено по методике сбора научной информации о маркетинговых коммуникациях в В2В и В2С секторах, их сравнения и анализа. В процессе исследования были исследованы мотивы производителей пищевых продуктов побуждающих их к экспорту для экспорта шаги и процедуры, различные типы сотрудничества с иностранными и внутренними покупателя и разницу между ними. А также разницу между сотрудничеством с покупателями из сектора Бизнес в Бизнеса и Бизнес в Потребителя.

Отмечено необходимость постоянной коммуникации с обоими секторами и целесообразность использования интернет ресурсов для обеспечения качественной коммуникации. Исследована разница в маркетинговых коммуникациях в вышеупомянутых секторах, и особенности выбора каждого из потенциальных клиентов. В статье также описаны различия в работе и маркетинговых коммуникациях в секторах Бизнес в Бизнеса и Бизнес в Потребителя. Предоставленные рекомендации способствуют ознакомлению производителей пищевых продуктов с процедурой экспорта пищевых продуктов, необходимой подготовке предприятий к экспорту и взаимодействию с различными типами клиентов.

Статья также включает в себя ключевые факторы которые побуждают представителей обоих секторов к покупке и потенциальные риски в работе с ними для производителей пищевых продуктов. Даны рекомендации для производителей пищевых продуктов из документации и сертификации продукции и предприятия необходимых для начала экспорта и поиска потенциальных клиентов в другой стране.

Ключевые слова: экспорт пищевых продуктов; выбор экспортного рынка; маркетинговые коммуникации; бизнес к бизнесу; бизнес к потребителю; подготовка предприятия к экспорту. 


\author{
Bohdan Shapoval \\ Postgraduate student, \\ U-Food Association, \\ Uman, Ukraine \\ ORCID ID: 0000-0001-9242-0552 \\ e-mail: kardvalr@gmail.com
}

\title{
COMMUNICATIONS FOR FOOD EXPORTS IN THE B2B AND B2C SECTORS OF THE FOOD MARKET
}

Abstract. The purpose of the study is to get acquainted with the factors that contribute to the export of products from the country, the processes of preparation of food producers for export and sales in the B2B and B2C sectors, the difference between them and the necessary marketing activities for different sectors. The analysis revealed the commodity items of food products that were most exported in 2019. The study was conducted using the method of collecting scientific information on marketing communications in the B2B and B2C sectors, their comparison and analysis.

The study examined the motives of food producers that motivate them to export, the steps and procedures required for export, the different types of cooperation with foreign and domestic buyers and the difference between them. As well as the difference between cooperation with buyers from the Business to Business sector and Business to the Consumer. The need for constant communication with both sectors and the feasibility of using Internet resources to ensure quality communication are identified. The difference in marketing communications in the above-mentioned sectors and the peculiarities of the choice of each of the potential clients are investigated.

The article also describes the differences in the work and marketing communications in the sectors Business to Business and Business to Consumer. The recommendations provided in the article help to acquaint food producers with the procedure of food export, the necessary preparation of enterprises for export and interaction with different types of customers. The article also includes key factors that motivate both sectors to buy and the potential risks of working with them for food producers. Recommendations are provided for food producers on documentation and certification of products and enterprises needed to start exporting and finding potential customers in another country.

Key words: food export; choice of export market; marketing communications; business to business; business to consumer; preparation of enterprise for export.

\section{REFERENCES}

1. Dukhnytskyi B. V. (2019) Potentsial rozvytku ahroprodovolchoho rynku Ukrainy. [Potential of agrofood market development in Ukraine]. Ekonomika APK.. № 11. [in Ukrainian].

2. Trade map, URL: https://www.trademap.org/Index.aspx [in English]

3. Navarro, A., Rondán, F. J., \& Acedo, F. J. (2013). The importance of an export-oriented culture for export performance. European Journal of International Management. 7 (3). [in English]

4. Povolná, L. (2017). Marketing Communications on B2B Markets. - Conference Proceedings of 13th Annual International Bata Conference for Ph.D. Students and Young Researchers, Tomas Bata University in Zlín, Czech Republic, April 26. P. 6 -20 [in English]

5. McDonald, M. (2016), "Marketing in B2B organisations: as it is; as it should be - a commentary for change”, Journal of Business \& Industrial Marketing, Vol. 31 No. 8, P. 961-970. [in English]

6. Alan Zimmerman and Jim Blythe, (2013) Business to Business Marketing Management. A Global Perspective. P. 5-11 [in English]

7. Réklaitis Kestutis, and Lina Pileliené. (2019). Principle Differences between B2B and B2C Marketing Communication Processes. Management of Organizations: Systematic Research 81: P 73-86. [in English]

8. Malinowska, M. (2013). Marketing Communications Effectiveness in Poland - Lessons from the Business in Information Society. The Central European Journal of Social Sciences and Humanities. Vol. 150, P. 133-143 [in English]

9. Camilleri, M. A. (2018). Integrated Marketing Communications. In Travel Marketing, Tourism Economics and the Airline Product. - Cham, Switzerland: Springer Nature, pp. 85-103 [in English]

10. Duralia, O. (2018). Integrated Marketing Communication and its Impact on Consumer Behavior. Studies in Business and Economics. Vol. 13, Issue 2, P. 92-102. doi:10.2478/sbe-2018-0022. [in English]

11. Kitchen, P. J. (2017). Integrated Marketing Communications. Evolution, Current Status, Future Developments. European Journal of Marketing. Vol. 51, Issue 3, P. 394-405. doi:10.1108/EJM-06-2016-0362. [in English] 
12. Kumar, V., Raheja, G. (2012). Business to Business (B2B) and Business to Consumer (B2C) Management. International Journal of Computers \& Technology. Vol. 3, No. 3, P. 447-451. [in English]

13. Owen, R., Humphrey, P. (2010). The Structure of Online Marketing Communication Channels. Journal of Management and Marketing Research. Vol. 2, P. 1-10. [in English]

14. Saha, S. K., Hossain, M. Sh., Islam, A., Rodela, R. S. (2014). A Comparative Study on B2B Vs. B2C Based on Asia Pacific Region. International Journal of Scientific \& Technology Research. Vol. 3, Issue 9, P. 294298 [in English]

15. Rehman, U. Sh., Ibrahim, M. S. (2011). Integrated Marketing Communication and Promotion. Journal of Arts, Science \& Commerce. Vol. 2, Issue 4, P. 1-5 [in English]

16. Murton Beets, L., Handley, A. (2019). B2C Content Marketing. Internet access: $<$ https://contentmarketinginstitute.com/wp-content/uploads/2018/12/2019_B2C_Research-FINALPDF12_10_18.pdf>, [accessed July 13, 2019]. [in English]

17. Todorova, G. (2015). Marketing Communication Mix. Trakia Journal of Sciences. Vol. 13, Suppl. 1, P. 368-374. doi:10.15547/tjs.2015.s.01.063. [in English]

18. Key, Th. M., Czaplewski, A. J. (2017). Upstream Social Marketing Strategy: An Integrated Marketing Communications Approach. Business Horizons. Vol. 60, Issue 3, P. 325-333. doi:10.1016/j.bushor.2017.01.006 [in English]

19. Kim, K. H., Kumar, V. (2018). The Relative Influence of Economic and Relational Direct Marketing Communications on Buying Behavior in Business-to-Business Markets. Journal of Marketing Research. Vol. 55, No. 1, P. 48-68. doi:10.1509/jmr.16.0283. [in English] 